UDC 57.032

\title{
Transcriptome-based identification of PDGFA as a candidate secreted biomarker for hepatocellular carcinoma
}

\author{
M. S. Chesnokov ${ }^{1}$, O. M. Krivtsova ${ }^{1,2}$, P. A. Skovorodnikova ${ }^{1,2}$, A. S. Makarova ${ }^{1,2}$, \\ I. F. Kustova ${ }^{1}$, M. D. Logacheva ${ }^{2}$, A. A. Penin ${ }^{2}$, A. V. Klepikova ${ }^{2}$, D. A. Shavochkina ${ }^{1}$, \\ N. E. Kudashkin ${ }^{1}$, E. A. Moroz ${ }^{1}$, Y. I. Patyutko ${ }^{1}$, E. A. Kotelnikova ${ }^{3}$, N. L. Lazarevich ${ }^{1,2}$ \\ ${ }^{1}$ N. N. Blokhin Russian Cancer Research Centre, RAMS \\ 24, Kashirskoye shosse, Moscow, Russian Federation, 115478 \\ ${ }^{2}$ M. V. Lomonosov Moscow State University \\ Leninskie Gory, 1/12, Moscow, Russian Federation, 119991 \\ ${ }^{3}$ ZAO Personal Biomedicine, \\ 124/17, Prospekt Mira, Moscow, Russian Federation, 129164 \\ lazarevich.nl@gmail.com
}

\begin{abstract}
Aim. Identification of candidate secreted biomarkers for hepatocellular carcinoma (HCC) diagnosis. Methods. Genes upregulated in HCC tissue and encoding secreted proteins were identified by RNA-seq. Gene expression changes in HCC were evaluated by RT-qPCR and meta-analysis of public databases. Biomarker properties were studied using ROC-curves, correlation and survival analysis. Results. PDGFA was identified by RNA-seq as an overexpressed gene encoding for a secreted protein in 5 HCC cases. PDGFA and GPC3 upregulation was revealed in 17 of $19 \mathrm{HCC}$ samples and in most cases from the public databases. Combination of PDGFA and GPC3 discerned HCC and non-tumor tissue better than PDGFA or GPC3 alone. PDGFA overexpression was associated with better overall survival of the patients at early HCC stage and with weaker tumor invasion into blood vessels. Conclusion. PDGFA is a valuable secreted biomarker for HCC that might be used in combination with GPC3 to increase its sensitivity.
\end{abstract}

Ke y w o r d s: hepatocellular carcinoma, PDGFA, tumor biomarker, NGS

\section{Introduction}

Hepatocellular carcinoma (HCC) is the most common form of malignant liver tumors with extremely high aggressiveness and poor prognosis. HCC ranks the second place in cancer-related mortality rates while most HCC patients are diagnosed at advanced stages when the existing therapeutic approaches become inefficient $[1,2]$.

The major difficulty in improving HCC diagnosis and treatment is imposed by a high heterogeneity of the genetic and signaling aberrations observed in HCC and poor understanding of molecular mecha- nisms underlying its development. Thus, the identification of new biomarkers suitable for an early diagnosis and potential therapeutic targets is an important field in improving the efficiency of HCC management [3].

Alpha-fetoprotein (AFP), the only HCC marker approved for clinical practice, has low sensitivity for early tumor detection [4,5]. Among additional HCC biomarkers under investigation, glypican-3 (GPC3) is the most promising one that demonstrates high sensitivity and specificity in tumor tissue but performs worse when detected in blood serum. The efficiency of HCC diagnosis can be improved by using

(C) 2016 M. S. Chesnokov et al.; Published by the Institute of Molecular Biology and Genetics, NAS of Ukraine on behalf of Biopolymers and Cell. This is an Open Access article distributed under the terms of the Creative Commons Attribution License (http://creativecommons.org/licenses/by/4.0/), which permits unrestricted reuse, distribution, and reproduction in any medium, provided the original work is properly cited 
combinations of biomarkers but remains insufficient to confidently detect HCC at early stages [5,6].

The next-generation sequencing (NGS) approaches open new possibilities in disclosing the molecular basis of carcinogenesis. The genomic and transcriptomic data revealed the multiple tumor-specific mutations and gene expression changes that can be further analyzed to identify putative biomarkers and changes in the signaling pathways regulating $\mathrm{HCC}$ progression. The present work is devoted to identification of novel prospective HCC biomarkers based on the results of transcriptome sequencing and investigation of their potential impact using experimental and bioinformatic approaches.

\section{Materials and Methods}

\section{Samples collection, $R N A$ extraction, transcriptome} sequencing and differential expression analysis

19 pairs of tumor and adjacent non-tumorous (NT) liver tissues were collected after tumor resection from the patients with histologically verified HCC not associated with hepatitis virus infection. The samples were collected with informed consent, conforming to the ethical guidelines of the 1975 Declaration of Helsinki, frozen in liquid nitrogen and stored at $-80{ }^{\circ} \mathrm{C}$. The clinicopathological data on collected cases are presented in Table 1.

Total RNA was isolated as previously described [7]. Illumina HiSeq2000 100 nt pair-end transcriptome sequencing was performed for 5 pairs of tumor and liver tissue in two biological replicates. Library preparation, transcriptome sequencing, read processing and differential expression analysis were performed as previously described [7].

\section{Quantitative Real-Time PCR}

Total RNA was reverse transcribed using random hexanucleotide primers and MMLV reverse transcriptase (Promega, USA).

Real-time RT-qPCR was carried out using SYBR Green I PCR kit (Syntol, Russian Federation) and iQ5 Multicolor Real-Time PCR Detection System (Bio-Rad Laboratories, USA). TATA-binding pro-
Table 1. Clinicopathological data on HCC patients enrolled in present study.

\begin{tabular}{|l|c|}
\hline \multicolumn{1}{|c|}{ Characteristics } & $\begin{array}{c}\text { Number } \\
\text { of cases } \\
(\mathrm{n}=19)\end{array}$ \\
\hline Age, years (mean $\pm \mathrm{SD})$ & $48.1 \pm 19.2$ \\
Gender, male/female & $11 / 8$ \\
TNM staging, I/II/III/IV & $4 / 4 / 6 / 5$ \\
Tumor size, cm (mean \pm SD) & $10.1 \pm 5.6$ \\
Tumor capsule, absent/feeble/prominent/N/A ${ }^{1}$ & $4 / 9 / 5 / 1$ \\
Blood vessel invasion, yes/no & $11 / 8$ \\
Tumor vascularity, low/moderate/high/N/A & $2 / 5 / 5 / 7$ \\
Histological differentiation, & $3 / 8 / 3 / 5$ \\
Edmondson-Steiner grade, G1/G2/G3/Gx ${ }^{2}$ & $8 / 11$ \\
Intrahepatic metastases, yes/no & $3 / 16$ \\
Lymph node metastases, yes/no & $1 / 18$ \\
Distant metastases, yes/no & $9 / 9$ \\
AFP serum level, & $5 / 14$ \\
low (<50 ng/ml)/high ( $>50$ ng/ml) & $12 / 7$ \\
Cirrhosis, yes/no & \\
Tumor necrosis, yes/no & \\
\hline
\end{tabular}

${ }^{1} \mathrm{~N} / \mathrm{A}$ - data not available

${ }^{2} \mathrm{Gx}$ - Edmondson-Steiner grade not applicable

tein gene $(T B P)$ was used as a reference gene. 45 cycles of amplification $\left(30 \mathrm{~s}\right.$ at $95^{\circ} \mathrm{C}, 30 \mathrm{~s}$ at annealing temperature $\left(P D G F A-66.0^{\circ} \mathrm{C}, G P C 3-67.7^{\circ} \mathrm{C}\right.$, $T B P-62.8^{\circ} \mathrm{C}$ ), 30 s at $72{ }^{\circ} \mathrm{C}$ ) were performed and the reaction specificity was checked afterwards by a melt curve analysis. The gene expression levels were estimated using a standard curve for fixed signal value. For each sample, the gene expression level was normalized to TBP expression, logarithm to base 2 was taken from normalized value and difference between the values obtained for HCC and corresponding NT samples was calculated.

The following primers were used for reactions: PDGFA-forward 5'-ACCACCGCAGCGTCAAGG3', PDGFA-reverse 5'-GCGGCTCATCCTCACCTC AC-3', GPC3-forward 5'-GCAGGAAAGCTGACC ACCAC-3', GPC3-reverse 5'-AGTTCCCTTCTTC GGCTGGAT-3',TBP-forward5'-TGCACAGGAGC CAAGAGTGA-3', TBP-reverse 5'-ACTTCACATC ACAGCTCCCCA-3'. 
Table 2. MIQE qPCR information table.

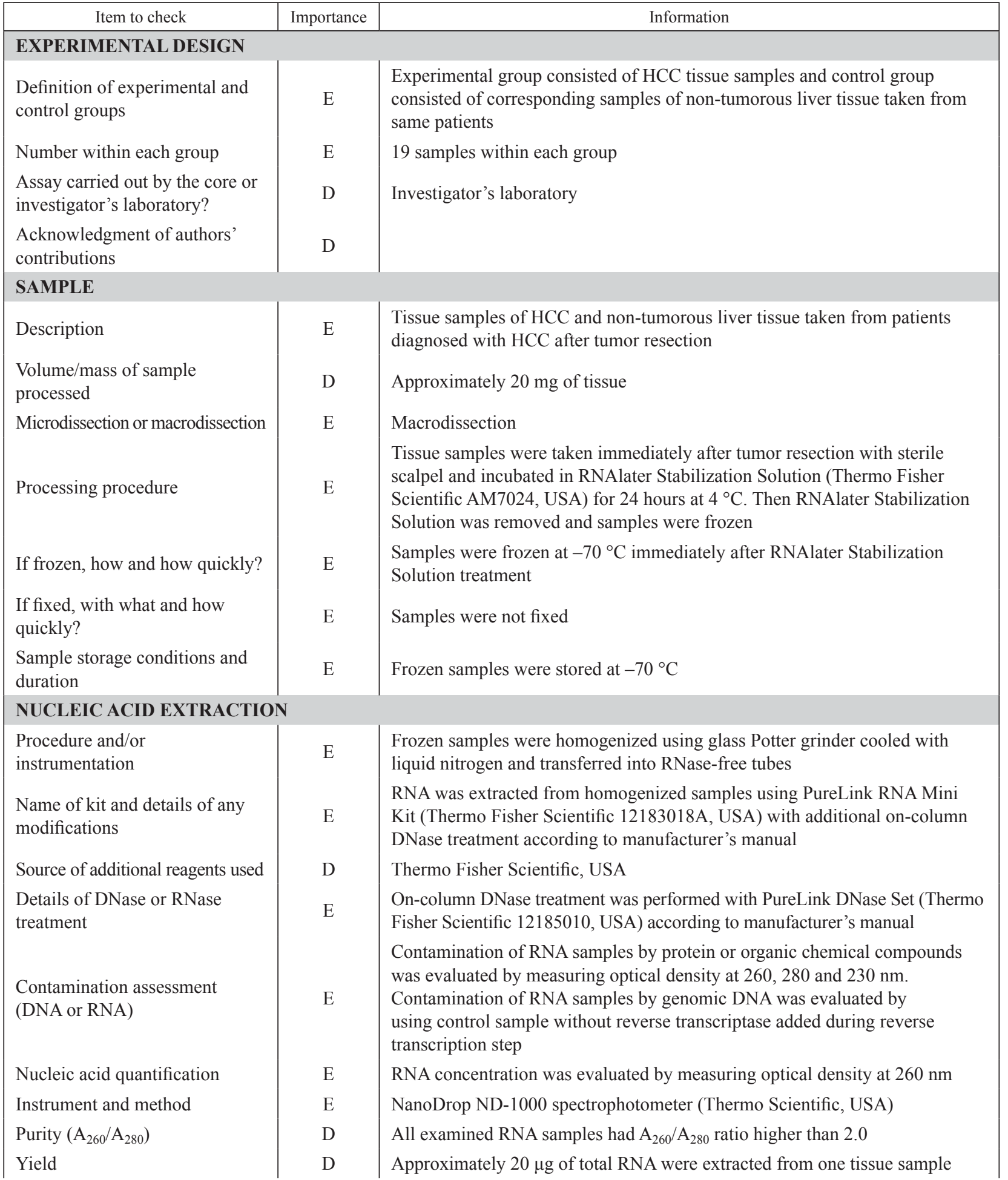


Transcriptome-based identification of PDGFA as a candidate secreted biomarker for hepatocellular carcinoma

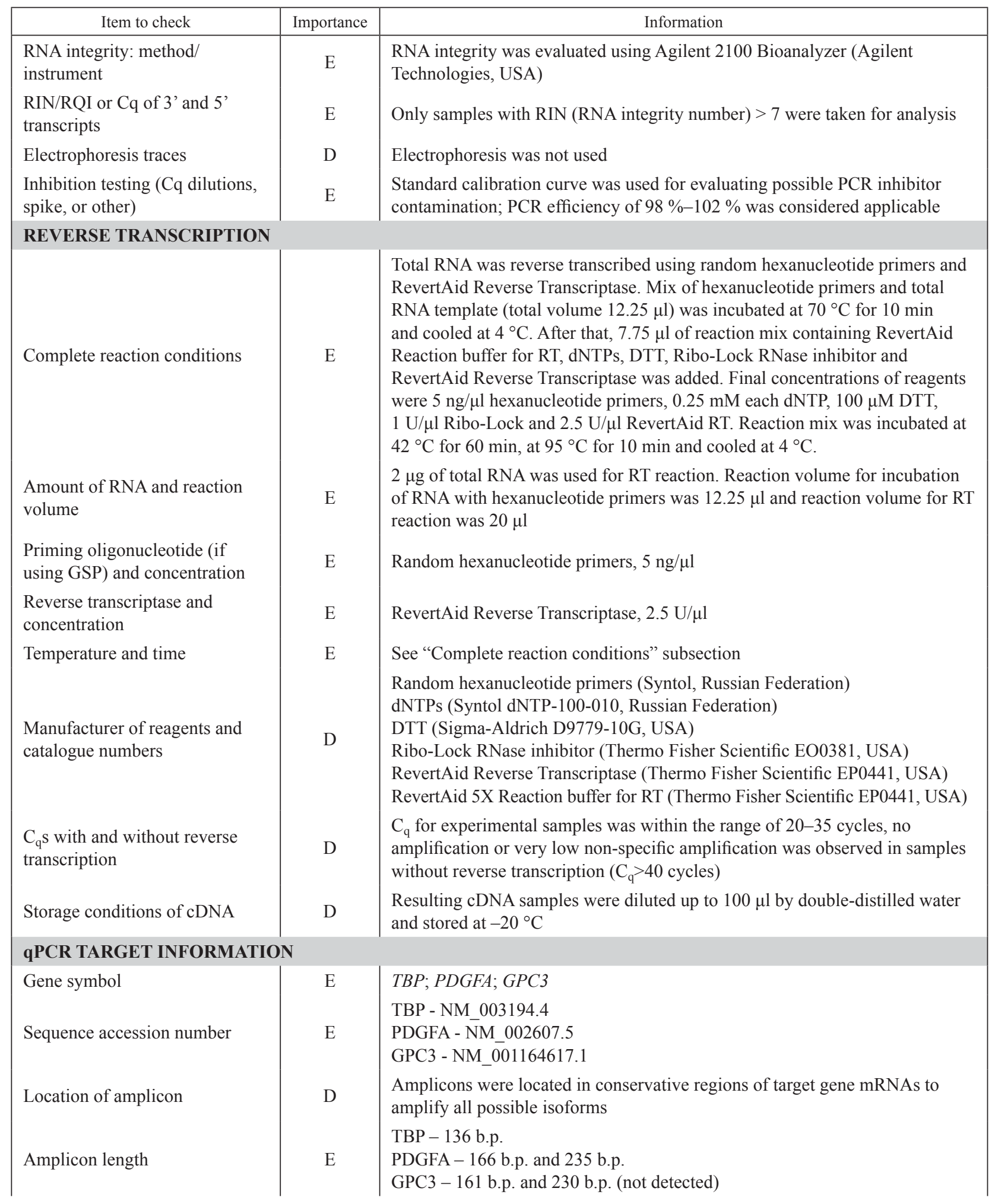




\begin{tabular}{|c|c|c|}
\hline Item to check & Importance & Information \\
\hline $\begin{array}{l}\text { In silico specificity screen } \\
\text { (BLAST, and so on) }\end{array}$ & E & $\begin{array}{l}\text { All primers were checked for specificity using NCBI Primer-BLAST service } \\
\text { (https://www.ncbi.nlm.nih.gov/tools/primer-blast/) }\end{array}$ \\
\hline $\begin{array}{l}\text { Pseudogenes, retropseudogenes, } \\
\text { or other homologs? }\end{array}$ & $\mathrm{D}$ & Primers were designed to prevent amplification of homologous templates \\
\hline Sequence alignment & $\mathrm{D}$ & Not evaluated \\
\hline $\begin{array}{l}\text { Secondary structure analysis of } \\
\text { amplicon }\end{array}$ & $\mathrm{D}$ & Not evaluated \\
\hline $\begin{array}{l}\text { Location of each primer by exon } \\
\text { or intron (if applicable) }\end{array}$ & $\mathrm{E}$ & $\begin{array}{l}\text { TBP-forward - exon } 5 \text { of NM_003194.4 transcript } \\
\text { TBP-reverse - exon } 6 \text { of NM_003194.4 transcript } \\
P D G F A \text {-forward - exon } 4 \text { of NM_002607.5 transcript } \\
\text { PDGFA-reverse - exon } 7 \text { of NM_002607.5 transcript } \\
G P C 3 \text {-forward - exon } 35 \text { of NM_004484.3 transcript } \\
G P G \text {-reverse - exon } 5 \text { of NM_004484.3 transcript }\end{array}$ \\
\hline $\begin{array}{l}\text { What splice variants are } \\
\text { targeted? }\end{array}$ & E & $\begin{array}{l}\text { TBP - NM_001172085, NM_003194 } \\
\text { PDGFA - NM_002607, NM_033023 } \\
G P C 3 \text { - NM_001164617, NM_001164618, NM_001164619, NM_004484 }\end{array}$ \\
\hline \multicolumn{3}{|l|}{ qPCR OLIGONUCLEOTIDES } \\
\hline Primer sequences & E & $\begin{array}{l}\text { TBP-forward - 5'-TGCACAGGAGCCAAGAGTGA-3' } \\
\text { TBP-reverse - 5'-ACTTCACATCACAGCTCCCCA-3' } \\
P D G F A \text {-forward - 5'-ACCACCGCAGCGTCAAGG-3' } \\
\text { PDGFA-reverse - 5'-GCGGCTCATCCTCACCTCAC-3' } \\
G P C 3 \text {-forward - 5'-GCAGGAAAGCTGACCACCAC-3' } \\
G P C \text {-reverse - 5'-AGTTCCCTTCTTCGGCTGGAT-3' }\end{array}$ \\
\hline $\begin{array}{l}\text { RTPrimerDB identification } \\
\text { number }\end{array}$ & $\mathrm{D}$ & Not applicable \\
\hline Probe sequences & $\mathrm{D}$ & Not applicable \\
\hline $\begin{array}{l}\text { Location and identity of any } \\
\text { modifications }\end{array}$ & E & Not applicable \\
\hline Manufacturer of oligonucleotides & $\mathrm{D}$ & Syntol, Russian Federation \\
\hline Purification method & $\mathrm{D}$ & PAAG electrophoresis \\
\hline \multicolumn{3}{|l|}{ qPCR PROTOCOL } \\
\hline Complete reaction conditions & $\mathrm{E}$ & $\begin{array}{l}\text { PCR was performed using SYBR Green I PCR kit (Syntol R- } 402 \text {, Russian } \\
\text { Federation). Reaction mix contained cDNA template, PCR buffer with SYBR } \\
\text { Green I dye, dNTPs, } \mathrm{MgCl}_{2} \text {, oligonucleotide primers and SynTaq DNA } \\
\text { polymerase. Following PCR protocol was used: } \\
\text { Initial denaturation }-5 \mathrm{~min} \text { at } 95^{\circ} \mathrm{C} \\
45 \text { PCR cycles }-30 \mathrm{sec} \text { at } 95^{\circ} \mathrm{C}, 30 \mathrm{sec} \text { at primer annealing temperature } \\
\text { (PDGFA }-66.0^{\circ} \mathrm{C}, \mathrm{GPC} 3-67.7^{\circ} \mathrm{C}, \mathrm{TBP}-62.8^{\circ} \mathrm{C} \text { ), } 30 \mathrm{sec} \text { at } 72{ }^{\circ} \mathrm{C} \\
\text { Final elongation }-3 \mathrm{~min} \text { at } 72^{\circ} \mathrm{C} \\
\text { Melt curve analysis - from } 60^{\circ} \mathrm{C} \text { up to } 100{ }^{\circ} \mathrm{C} \text { with increment of } 0.5^{\circ} \mathrm{C}\end{array}$ \\
\hline $\begin{array}{l}\text { Reaction volume and amount of } \\
\text { cDNA/DNA }\end{array}$ & $\mathrm{E}$ & $\begin{array}{l}\text { PCR was performed in a volume of } 25 \mu 1 \text {, cDNA sample (see "Storage } \\
\text { conditions of cDNA" subsection) was diluted ten-times and } 10 \mu \text { lof diluted } \\
\text { cDNA sample were added to the reaction mix }\end{array}$ \\
\hline $\begin{array}{l}\text { Primer, (probe), } \mathrm{Mg}^{2+} \text {, and } \\
\text { dNTP concentrations }\end{array}$ & $\mathrm{E}$ & $0.4 \mu \mathrm{M}$ of each primer, $2.5 \mu \mathrm{M} \mathrm{Mg}^{2+}, 0.25 \mathrm{mM}$ dNTPs \\
\hline
\end{tabular}


Transcriptome-based identification of PDGFA as a candidate secreted biomarker for hepatocellular carcinoma

\begin{tabular}{|c|c|c|}
\hline Item to check & Importance & Information \\
\hline $\begin{array}{l}\text { Polymerase identity and } \\
\text { concentration }\end{array}$ & $\mathrm{E}$ & SynTaq DNA polymerase (Syntol E-039-1000, Russian Federation) \\
\hline $\begin{array}{l}\text { Buffer/kit identity and } \\
\text { manufacturer }\end{array}$ & $\mathrm{E}$ & SYBR Green I PCR kit (Syntol R-402, Russian Federation). \\
\hline $\begin{array}{l}\text { Exact chemical composition of } \\
\text { the buffer }\end{array}$ & $\mathrm{D}$ & Not specified by manufacturer \\
\hline $\begin{array}{l}\text { Additives (SYBR Green I, } \\
\text { DMSO, and so forth) }\end{array}$ & $\mathrm{E}$ & SYBR Green I dye was pre-added to PCR buffer by manufacturer \\
\hline $\begin{array}{l}\text { Manufacturer of plates/tubes and } \\
\text { catalog number }\end{array}$ & $\mathrm{D}$ & $0.2 \mathrm{ml}$ PCR strips with domed caps (SSI 3240-00, USA) \\
\hline $\begin{array}{l}\text { Complete thermocycling } \\
\text { parameters }\end{array}$ & $\mathrm{E}$ & See "Complete reaction conditions" subsection \\
\hline Reaction setup (manual/robotic) & $\mathrm{D}$ & Manual \\
\hline $\begin{array}{l}\text { Manufacturer of qPCR } \\
\text { instrument }\end{array}$ & $\mathrm{E}$ & $\begin{array}{l}\text { iCycler Thermal Cycler with iQ5 Multicolor Real-Time PCR Detection } \\
\text { System, data were analyzed using iQ5 Optical System Software (Bio-Rad } \\
\text { Laboratories, USA) }\end{array}$ \\
\hline \multicolumn{3}{|l|}{ qPCR VALIDATION } \\
\hline $\begin{array}{l}\text { Evidence of optimization (from } \\
\text { gradients) }\end{array}$ & $\mathrm{D}$ & $\begin{array}{l}\text { Primer annealing temperature was optimized for each primer set using qPCR } \\
\text { with temperature gradient to achieve reaction efficiency of } 98 \%-102 \% \text { and } \\
\text { minimize non-specific amplification }\end{array}$ \\
\hline $\begin{array}{l}\text { Specificity (gel, sequence, melt, } \\
\text { or digest) }\end{array}$ & $\mathrm{E}$ & Specificity of qPCR was determined using melt curve analysis \\
\hline $\begin{array}{l}\text { For SYBR Green } \mathrm{I}, \mathrm{C}_{\mathrm{q}} \text { of the } \\
\text { NTC }\end{array}$ & $\mathrm{E}$ & $\begin{array}{l}\text { No amplification or very low non-specific amplification was observed in } \\
\text { samples without reverse transcription and in NTC samples }\left(\mathrm{C}_{\mathrm{q}}>40 \text { cycles }\right)\end{array}$ \\
\hline $\begin{array}{l}\text { Calibration curves with slope } \\
\text { and y intercept }\end{array}$ & $\mathrm{E}$ & $\begin{array}{l}\text { Slope and y intercept values: } \\
T B P-\text { slope }=-3.283, \mathrm{y} \text { int }=31.467 \\
P D G F A-\text { slope }=-3.339, \mathrm{y} \text { int }=30.015 \\
G P C 3-\text { slope }=-3.301, \mathrm{y} \text { int }=26.564\end{array}$ \\
\hline $\begin{array}{l}\text { PCR efficiency calculated from } \\
\text { slope }\end{array}$ & $\mathrm{E}$ & $\begin{array}{l}T B P-\mathrm{E}=101.6 \% \\
P D G F A-\mathrm{E}=99.3 \% \\
G P C 3-\mathrm{E}=100.9 \%\end{array}$ \\
\hline CIs for PCR efficiency or SE & $\mathrm{D}$ & Not evaluated \\
\hline $\mathrm{r}^{2}$ of calibration curve & $\mathrm{E}$ & $\begin{array}{l}T B P-\mathrm{E}=0.996 \\
P D G F A-\mathrm{E}=0.998 \\
G P C 3-\mathrm{E}=0.998\end{array}$ \\
\hline Linear dynamic range & $\mathrm{E}$ & $\begin{array}{l}\text { Standard curve was linear within the limits of cDNA dilutions from non- } \\
\text { diluted samples up to } 1 / 10000 \text { dilution for all primers used }\end{array}$ \\
\hline $\mathrm{C}_{\mathrm{q}}$ variation at LOD & $\mathrm{E}$ & $\begin{array}{l}\mathrm{SD} \text { of } \mathrm{C}_{\mathrm{q}} \text { values for } 1 / 10000 \text { dilution sample: } \\
T B P-0.83 \\
P D G F A-0.77 \\
G P C 3-0.37\end{array}$ \\
\hline CIs throughout range & $\mathrm{D}$ & Not evaluated \\
\hline Evidence for LOD & $\mathrm{E}$ & High variation of $\mathrm{C}_{\mathrm{q}}$ values obtained for $1 / 10000$ dilution sample \\
\hline $\begin{array}{l}\text { If multiplex, efficiency and LOD } \\
\text { of each assay }\end{array}$ & $\mathrm{E}$ & Displayed above \\
\hline
\end{tabular}




\begin{tabular}{|c|c|c|}
\hline Item to check & Importance & Information \\
\hline \multicolumn{3}{|l|}{ DATA ANALYSIS } \\
\hline $\begin{array}{l}\text { qPCR analysis program (source, } \\
\text { version) }\end{array}$ & $\mathrm{E}$ & $\begin{array}{l}\text { Data were analyzed using iQ5 Optical System Software, v2.0 (Bio-Rad } \\
\text { Laboratories, USA) }\end{array}$ \\
\hline Method of $\mathrm{C}_{\mathrm{q}}$ determination & $\mathrm{E}$ & $\begin{array}{l}\mathrm{C}_{\mathrm{q}} \text { values were determined by setting a signal threshold. Threshold value was } \\
\text { adjusted to detect the amplification of samples during log-phase of PCR and at } \\
\text { the same time to be significantly higher than background signal }\end{array}$ \\
\hline $\begin{array}{l}\text { Outlier identification and } \\
\text { disposition }\end{array}$ & $\mathrm{E}$ & $\begin{array}{l}\text { Data were checked for outliers using Grubbs' test, no significant outliers were } \\
\text { detected }\end{array}$ \\
\hline Results for NTCs & $\mathrm{E}$ & $\begin{array}{l}\text { No amplification or very low non-specific amplification was observed in } \\
\text { samples without reverse transcription and in NTC samples }\left(C_{q}>40 \text { cycles }\right)\end{array}$ \\
\hline $\begin{array}{l}\text { Justification of number and } \\
\text { choice of reference genes }\end{array}$ & $\mathrm{E}$ & $\begin{array}{l}\text { TBP was chosen as a reference gene based on lowest variability of its } \\
\text { expression level in } 10 \text { samples ( } 5 \text { HCC samples and } 5 \text { corresponding } \\
\text { non-tumorous tissue samples) examined by RNAseq approach. Low TBP } \\
\text { expression variability was validated on TCGA-LIHC RNAseq dataset } \\
\text { (see Materials and Methods). This experimental evidence is supported by } \\
\text { previously published data }[9,10] \text { while the expression of other reference gene, } \\
\text { HPRT was found to be variable in some non-HBV related HCC samples. }\end{array}$ \\
\hline $\begin{array}{l}\text { Description of normalization } \\
\text { method }\end{array}$ & $\mathrm{E}$ & $\begin{array}{l}\text { For each sample, target gene expression was normalized to } T B P \text { expression. } \\
\text { Level of target gene expression was divided by level of } T B P \text { expression prior } \\
\text { to comparing different samples }\end{array}$ \\
\hline $\begin{array}{l}\text { Number and concordance of } \\
\text { biological replicates }\end{array}$ & $\mathrm{D}$ & $\begin{array}{l}\text { Not applicable since one HCC tissue and one non-tumorous tissue samples } \\
\text { were taken from each patient }\end{array}$ \\
\hline $\begin{array}{l}\text { Number and stage (reverse } \\
\text { transcription or qPCR) of } \\
\text { technical replicates }\end{array}$ & $\mathrm{E}$ & At least 3 technical replicates were analyzed in each qPCR reaction \\
\hline Repeatability (intraassay variation) & $\mathrm{E}$ & Average $\mathrm{CV}$ for technical replicates was 0.22 \\
\hline $\begin{array}{l}\text { Reproducibility (interassay } \\
\text { variation, CV) }\end{array}$ & $\mathrm{D}$ & Not evaluated \\
\hline Power analysis & $\mathrm{D}$ & Not evaluated \\
\hline $\begin{array}{l}\text { Statistical methods for results } \\
\text { significance }\end{array}$ & $\mathrm{E}$ & $\begin{array}{l}\text { Changes in expression level that were higher than 2-fold were considered } \\
\text { significant when comparing HCC and non-tumorous tissue samples from same } \\
\text { patient. Differences between gene expression levels in HCC and NT sample } \\
\text { sets were estimated using paired sample sign test (for sets of paired samples) } \\
\text { and Mann-Whitney U-test (for sets of unpaired samples). }\end{array}$ \\
\hline Software (source, version) & E & Origin Pro 2016 software (OriginLab Corporation, USA) \\
\hline $\begin{array}{l}\mathrm{C}_{\mathrm{q}} \text { or raw data submission with } \\
\mathrm{RDML}\end{array}$ & $\mathrm{D}$ & Not submitted \\
\hline
\end{tabular}

All relevant qPCR conditions and characteristics determined by the MIQE Guidelines [8] are described in Table 2.

\section{Hepatocellular carcinoma datasets}

Publicly available datasets containing information on gene expression in paired liver-HCC samples and their clinical data were acquired from GEO database (https://www.ncbi.nlm.nih.gov/geo): GSE14520 [11], GSE25599 [12], GSE5364 [13], GSE65485 [14], GSE77314 [15]. PDGFA expression data generated using 205463_s_at probe set were considered for GSE14520 as it targets both PDGFA isoforms.

TCGA Liver Hepatocellular Carcinoma (TCGALIHC) set that comprised information on the normalized gene expression in 51 matched liver and tumor 
tissues and 321 tumors corresponding to a pooled normal sample was obtained from The Cancer Genome Atlas Network (https://gdc-portal.nci.nih.gov/) through FireBrowse (http://www.firebrowse.org). The clinical and survival data were downloaded at cBioPortal (http://www.cbioportal.org).

\section{Statistical analysis}

Each tissue sample used for RT-qPCR was analyzed in at least four technical replicates and a mean value was used for further analysis. The statistical analysis of results and plotting of graphs were performed using Origin Pro 2016 software (OriginLab Corporation, USA). The differences between gene expression levels in HCC and NT samples were estimated using a paired sample sign test (for paired samples) and Mann-Whitney U-test (for unpaired samples). The empirical distribution curves for gene expression in different datasets were compared using KolmogorovSmirnov test. The hierarchical cluster analysis of gene expression datasets was performed using Euclidean distance and Complete linkage algorithm. Receiver operating characteristic (ROC) curve discriminative power analysis was performed using the normalized gene expression level for classifier, HCC samples for estimation of true positive rate and NT samples from the same patients for estimation of false positive rate. The combined PDGFA+GPC3 classifier for ROC curves was generated by applying a logistic regression model to the data on both PDGFA and GPC3 expression levels and taking the values of expected probabilities as a new classifier. The correlations were evaluated using Spearman's rank correlation test. A survival analysis was performed using Kaplan-Meyer test with log-rank significance estimation algorithm. Statistical significance was accepted with $\mathrm{p}<0.05$.

\section{Results}

The whole transcriptome data analysis using DESeq [16] revealed 83 differentially expressed (DE)

Table 3. Potential secreted HCC markers that were significantly upregulated in $\mathbf{5}$ sequenced HCC cases

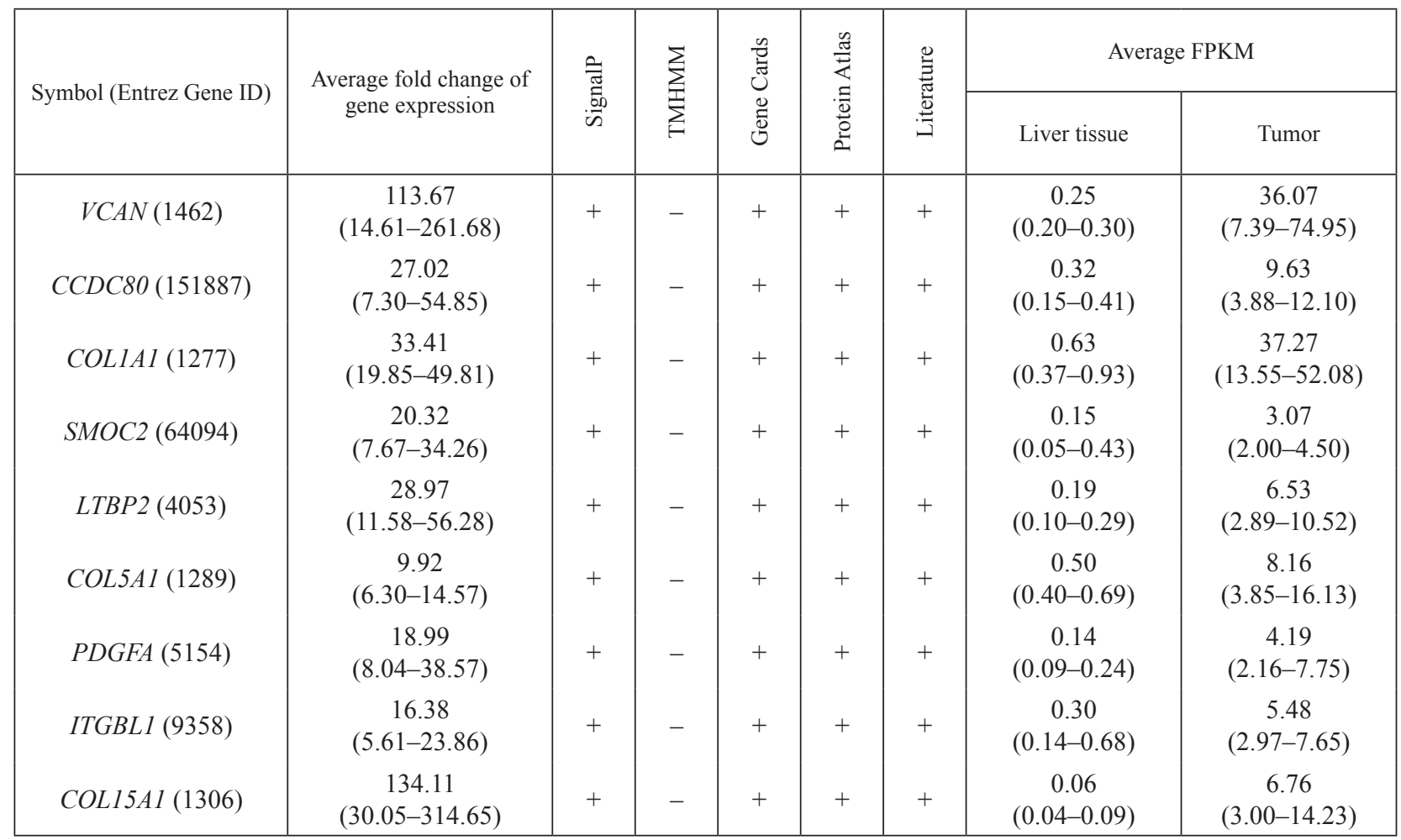


genes that were up-regulated more than 5-fold in all HCC samples as compared to corresponding adjacent liver tissue. In order to identify putative secreted HCC markers, the FASTA sequences of all mRNA isoforms of DE genes were analyzed with SignalP Server 4.1 (http://www.cbs.dtu.dk/services/SignalP/) and TMHMM Server v. 2.0 (http:// www.cbs.dtu.dk/services/TMHMM/) using default settings. The genes harboring sequences that were predicted to encode the signal peptide cleavage sites but not transmembrane helices were examined using GeneCards (http://www.genecards.org/), The Human Protein Atlas (http://www.proteinatlas.org/) and the information from journal articles. Then we excluded the genes that were valuably expressed in normal liver (FPKM $>1$ ) and/or demonstrated relatively low level of expression in tumors $(\mathrm{FPKM}<2)$. Thus, we obtained a list comprising 9 potential secreted HCC markers (Table 3).

The list of candidate serum markers includes growth factor PDGFA, a component of PDGF signaling pathway identified in our recently published HCC
$\boldsymbol{A}$

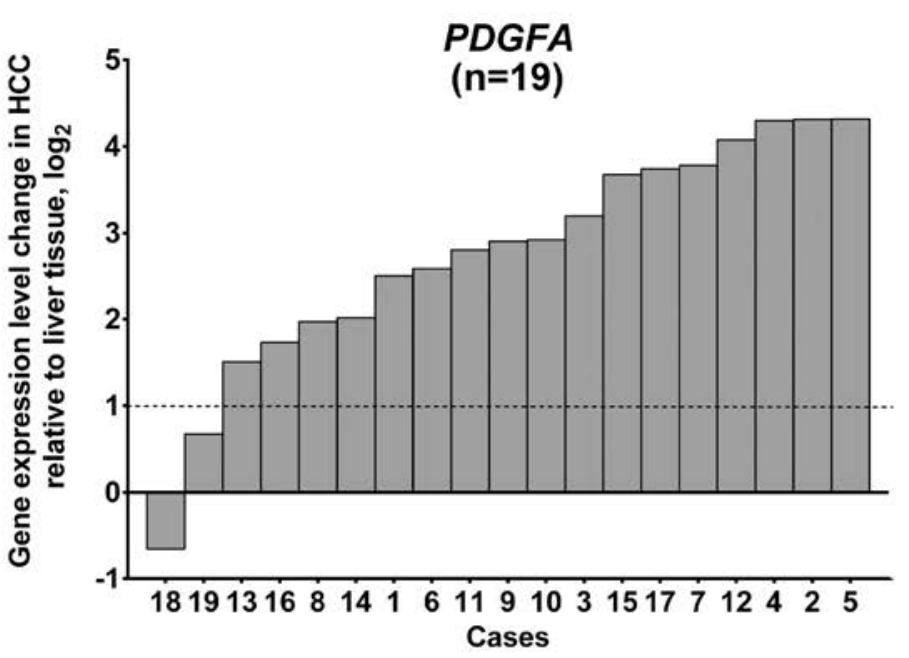

C

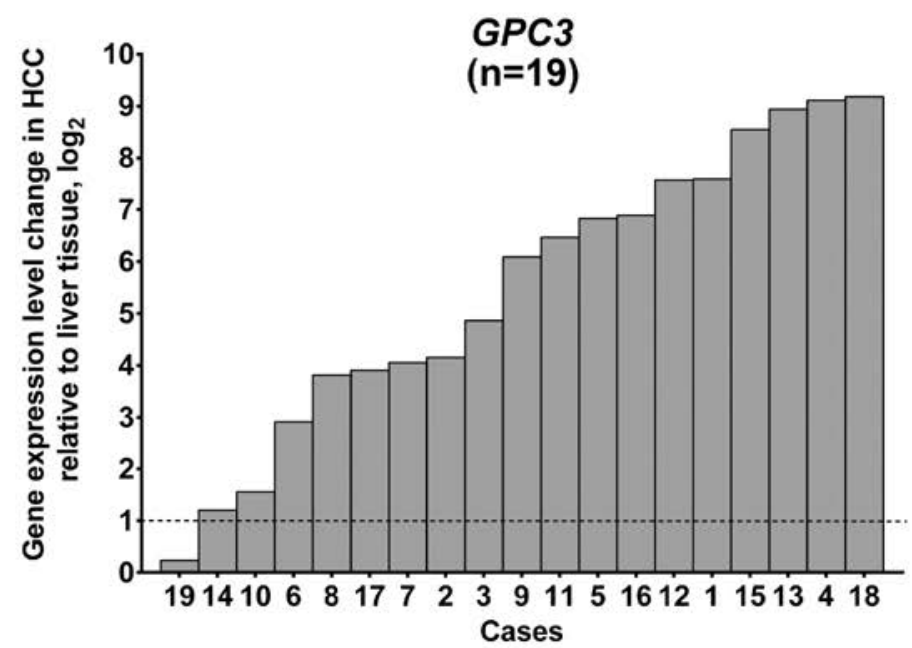

$\boldsymbol{B}$

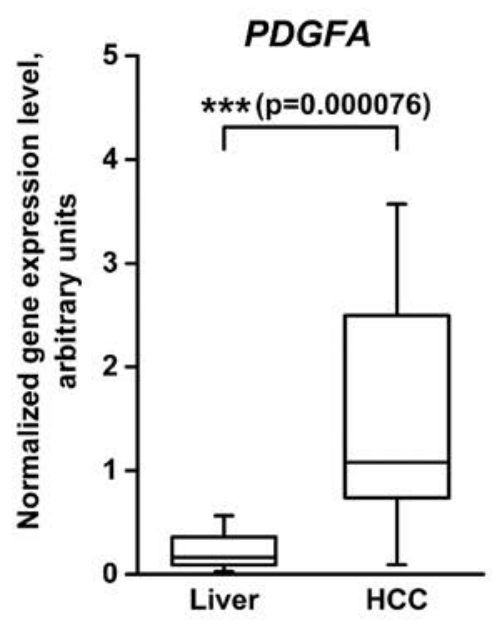

D

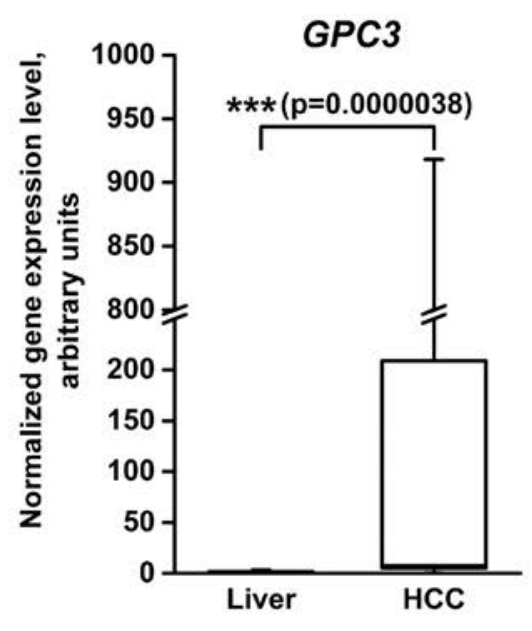

Fig. 1. Alteration of PDGFA $(A, B)$ and $G P C 3(C, D)$ expression in examined HCC tissue samples. $A, \mathrm{C}$ - RT-qPCR analysis of $P D G F A$ or $G P C 3$ expression changes in HCC specimens relative to matching non-tumor liver tissue for individual cases. $B, D-$ Box plot representation of TBP-normalized expression levels of PDGFA and GPC3 in examined sets of HCC and NT samples (n=19). 
case report as a potential druggable target [7]. Since the proangiogenic and mitogenic stimulation promoted by PDGF signaling can be blocked by a multikinase inhibitor sorafenib, the only FDA approved drug for HCC treatment $[17,18]$, we have focused on investigation of the expression alterations of PDGFA that might be not only a candidate HCC marker but also a prospective target for drug treatment.

To explore HCC-specific changes in PDGFA expression we performed RT-qPCR analysis of PDGFA expression levels in 19 pairs of tumor and NT tissues from hepatitis-negative HCC patients. While low $P D G F A$ expression levels were detected in all NT specimens, the PDGFA expression in HCC tissue was upregulated more than two-fold in 17 of 19 (89.5\%) examined cases (Fig. 1A) and the difference between these two subsets was statistically significant (Fig. 1B).

We investigated the potential of PDGFA usage as a biomarker by comparing its expression changes in $\mathrm{HCC}$ tissue to the expression changes of $G P C 3$, the latter being a promising candidate biomarker for HCC [19]. RT-qPCR analysis revealed the significant GPC3 overexpression in HCC compared to NT tissue (Fig. 1D) in 18 of 19 (94.7\%) cases (Fig. 1C). Spearman's correlation analysis demonstrated that the changes in PDGFA expression were not associated with the clinicopathological properties of examined tumors.

In order to determine whether the PDGFA up-regulation discovered in the examined sample set is a frequent event in HCC we performed meta-analysis of the gene expression data for paired HCC/NT samples obtained from six publicly available datasets (Table 4). Each of the analyzed datasets displayed a significant (more than 2-fold) up-regulation of the PDGFA transcription in tumor tissue compared to the corresponding surrounding liver samples in no less than $50 \%$ of cases. Since several datasets comprised the data on a low number of samples, we further analyzed TCGA ("TCGA set") and GSE14520 ("Roessler set") datasets.

The ratios of cases with significant PDGFA upregulation ranged from $52.4 \%$ ("Roessler set") to $63.8 \%$ ("TCGA set") (Fig. 2A). Median values of normalized $P D G F A$ expression level were signifi- cantly higher in cohorts of HCC tissue samples than in cohorts of corresponding NT specimens (Fig. 2B).

While both datasets support the observation of PDGFA up-regulation being a frequent event in HCC tissue, the percentage of $P D G F A$ overexpressing samples is less than observed in our experimental set. To explore whether this difference could be associated with hepatitis infection we subtracted a fraction of 94 TCGA cases that were not marked as hepatitis-positive (hereinafter called "TCGA-HN set" for "hepatitis-negative"). The proportion of cases with up-regulated PDGFA expression in "TCGAHN set" (68.1\%) (Fig. 2A) was very similar to the one observed in full "TCGA set", while no statistically significant differences between full and "HN" sets in the context of PDGFA expression level median values ( $p=0.558$ estimated by Mann-Whitney U-test) and the empirical distribution curve ( $p=0.988$ estimated by Kolmogorov-Smirnov test) were found thus indicating that PDGFA up-regulation in $\mathrm{HCC}$ occurs irrespectively of tumor etiology.

To evaluate the PDGFA potential sensitivity as a HCC biomarker we compared the PDGFA expression changes in "Roessler set" and "TCGA-HN set" to the alterations of GPC3 expression (Fig. 3A). While the

Table 4. Overexpression of $P D G F A$ in HCC in six datasets comprising paired normal-tumor samples.

\begin{tabular}{|c|c|c|c|c|}
\hline Dataset ID & 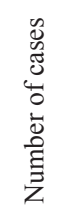 & 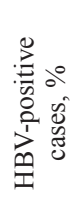 & 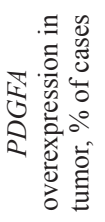 & $\begin{array}{l}\text { Gene expression } \\
\text { profiling method }\end{array}$ \\
\hline TCGA-LIHC & 373 & 75 & 63.8 & RNAseq \\
\hline GSE14520 & 231 & 98 & 52.4 & $\begin{array}{l}\text { Affymetrix } \\
\text { Human Genome } \\
\text { HT U133A Array }\end{array}$ \\
\hline GSE25599 & 10 & 100 & 50 & RNAseq \\
\hline GSE5364 & 8 & N/A & 100 & $\begin{array}{l}\text { Affymetrix } \\
\text { HG U133A } \\
\text { microarray }\end{array}$ \\
\hline GSE77314 & 50 & N/A & 60 & RNAseq \\
\hline GSE65485 & 8 & 100 & 75 & RNAseq \\
\hline
\end{tabular}

${ }^{1} \mathrm{~N} / \mathrm{A}$ - data not available 
sensitivity of PDGFA (52.4\% for "Roessler set", $68.1 \%$ for "TCGA-HN set") was lower than that of GPC3 $(87.4 \%$ for "Roessler set", $81.9 \%$ for "TCGA-HN set"), the combination of PDGFA and GPC3 increased the sensitivity to $93.9 \%$ for "Roessler set" and $93.6 \%$ for "TCGA-HN set" ( $\mathrm{p}=0.024$ for both sets compared to GPC3 alone, estimated by Fisher's exact test).

In order to evaluate the possibility of using the expression level of PDGFA, GPC3 or both genes as a parameter discerning $\mathrm{HCC}$ from NT tissue, we
A
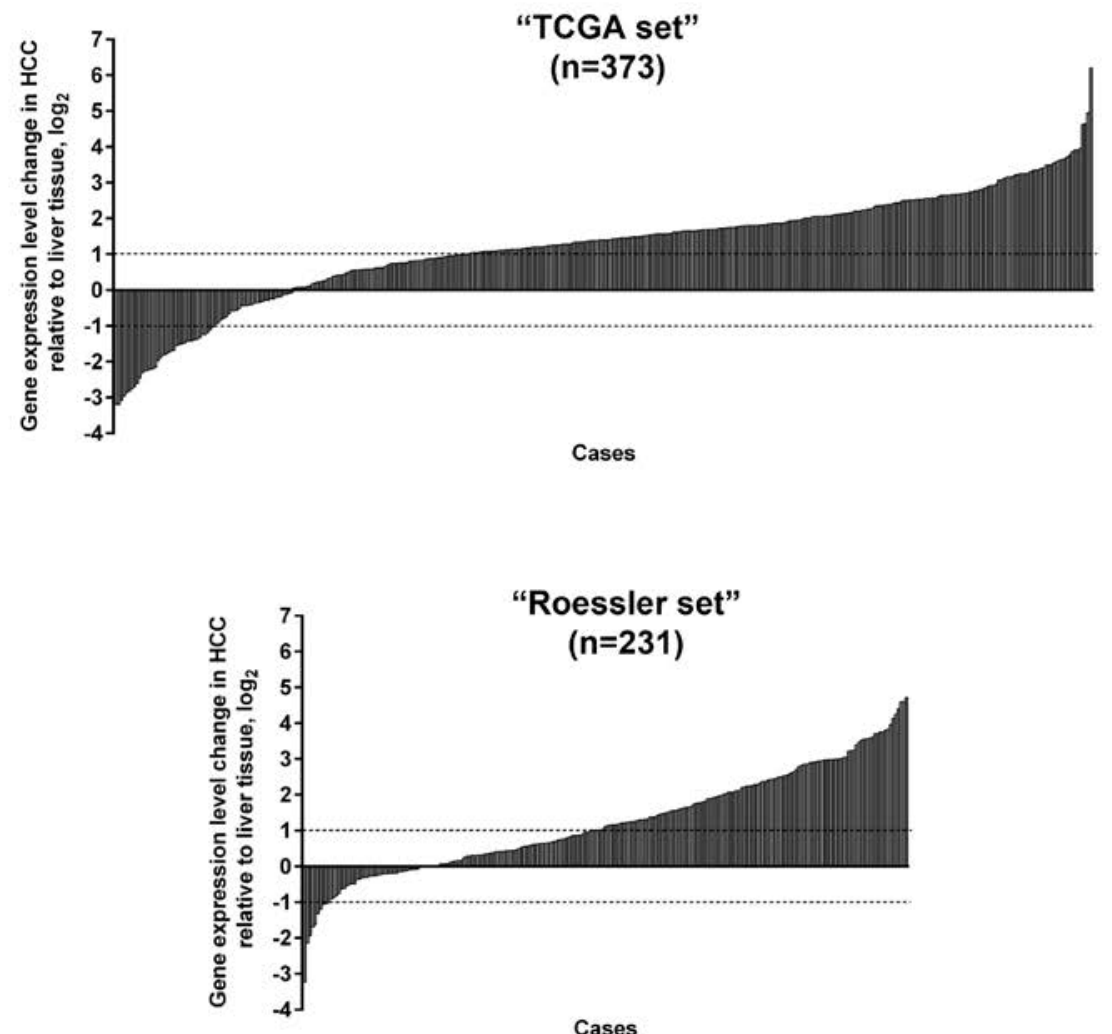

Cases

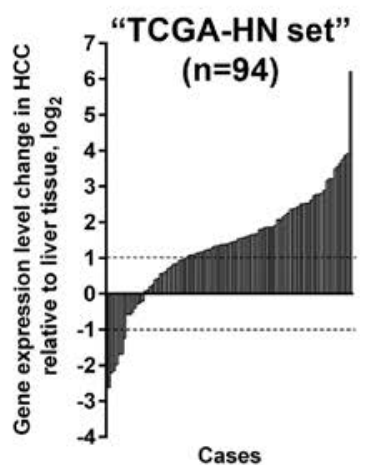

B
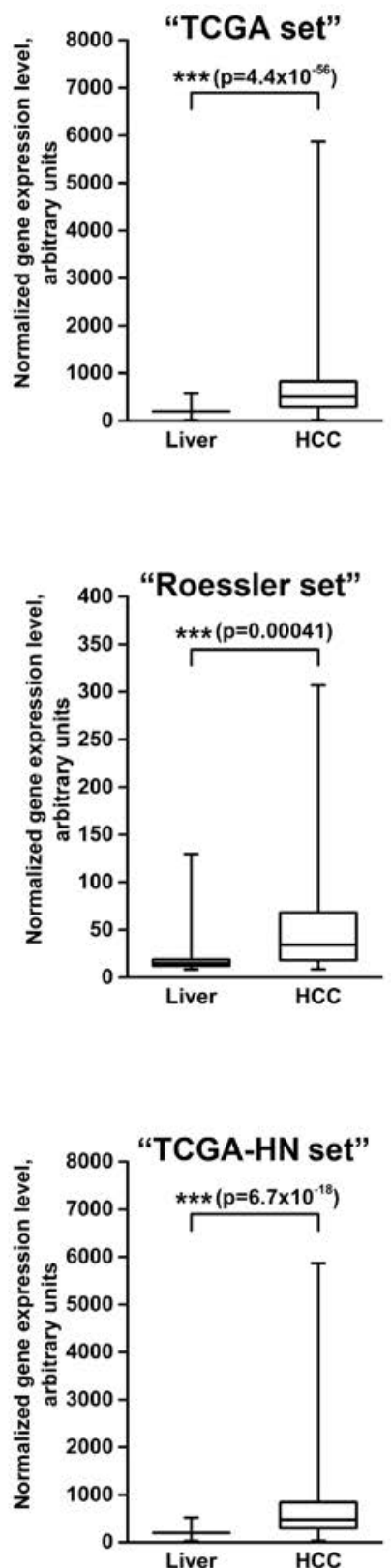

Fig. 2. Alteration of $P D G F A$ expression observed in publicly available HCC datasets. $A$ - Distribution curves of $P D G F A$ expression level changes in individual HCC samples compared to NT samples. $B$ - Box plot representation of normalized expression levels of $P D G F A$ in examined sets of HCC and NT samples. 
generated ROC curves using the data for paired samples from "Roessler set" (n=231) and "TCGA-HN set" ( $\mathrm{n}=24)$. Usage of the PDGFA+GPC3 combination increased the value of area under a curve (AUC) in comparison to PDGFA or GPC3 alone, thus indicating a stronger discriminative power of the $P D G F A$ and GPC3 combination (Fig. 3B).

A correlation analysis of the PDGFA expression changes and clinicopathological characteristics available for "TCGA-HN set" revealed a reverse correlation of the PDGFA up-regulation with the extent of tumor invasion into blood vessels.
Since "Roessler set" contains the data on Barcelona Clinic Liver Cancer (BCLC) staging which is widely used for evaluation of prognosis and treatment algorithm for HCC patients [20] we analyzed an association between the PDGFA up-regulation and overall and progression-free survival of patients belonging to different BCLC groups. The $P D G F A$ overexpression in tumor tissue was associated with better overall survival of patients with early BCLC-0 and BCLC-A HCC stages but not intermediate BCLC-B or late BCLC-C stage (Fig. 4). No associations between the $P D G F A$ overexpression
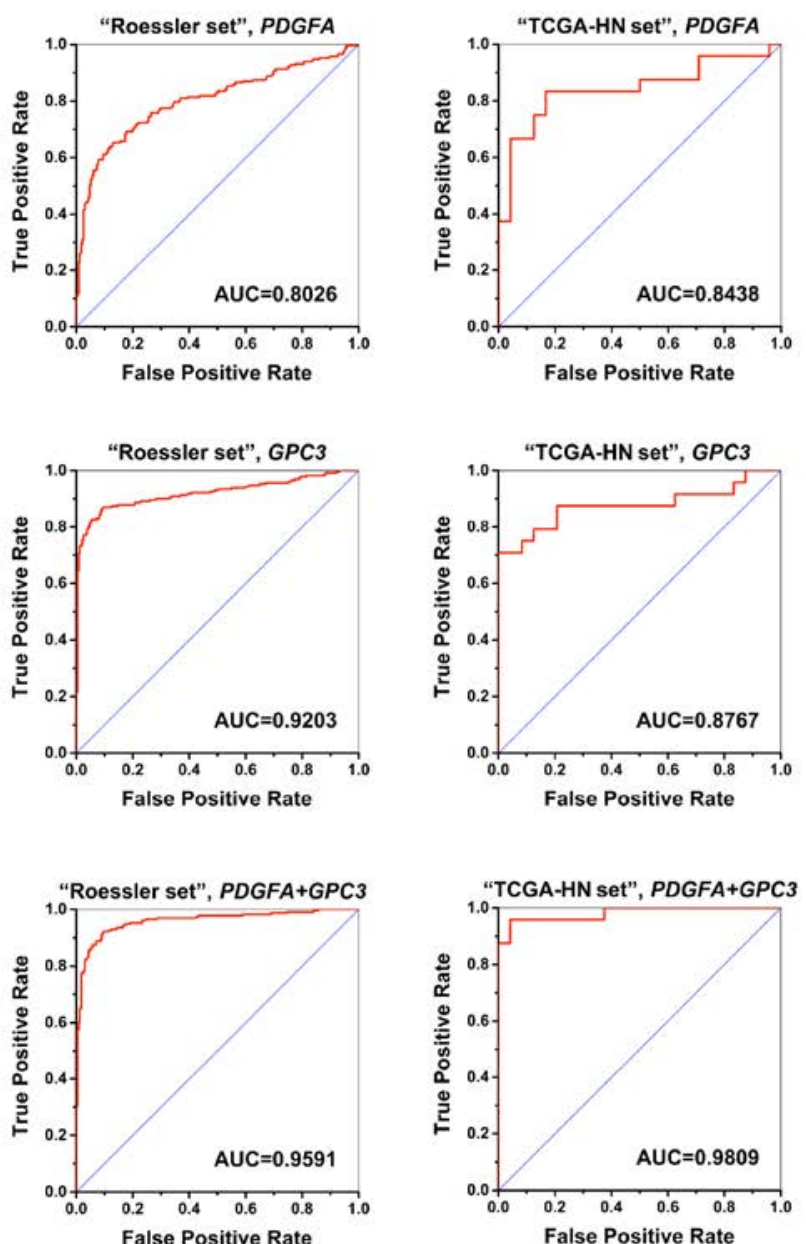

Fig. 3. Comparison of PDGFA and GPC3 expression changes in $\mathrm{HCC}$ and NT tissue samples from publicly available datasets. $A-$ Heatmap representation of PDGFA and GPC3 expression changes in HCC specimens from "Roessler set" and "TCGA-HN set". Color bar indicates the alteration of gene expression in tumor tissue relative to NT sample in $\log _{2}$ scale. $B-$ ROC curves representing the ability of PDGFA, GPC3 or PDGFA+GPC3 combination to discriminate HCC and NT tissue samples. 

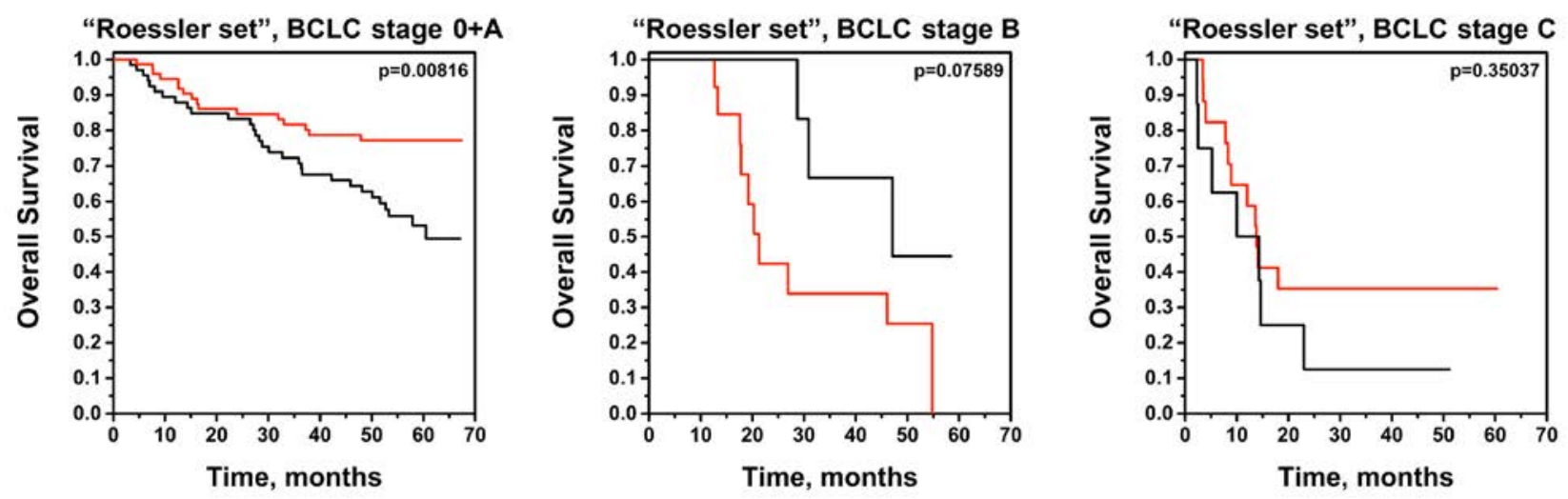

PDGFA upregulation

no PDGFA upregulation

Fig. 4. Kaplan-Meyer analysis of association between PDGFA up-regulation and overall survival of patients from "Roessler set" belonging to different BCLC groups.

and progression-free survival were found (data not shown).

\section{Discussion}

The discovery of tumor biomarkers significantly improved the outcome for cancer patients and opened new possibilities for early diagnosis and targeted treatment of malignant tumors [21]. The only serum HCC biomarker approved for clinical practice is AFP [4] that displays 59\% sensitivity and 90\% specificity [22]. Since AFP exhibits insufficient sensitivity for the confident HCC diagnosis, the additional markers to complement AFP and improve HCC diagnostic accuracy are under investigation [23].

Currently GPC3 is considered to be one of the most promising $\mathrm{HCC}$ candidate biomarkers. It can be detected at the mRNA level in liver tissue or at the protein level in serum or liver tissue. Immunohistochemical detection of GPC3 demonstrates a high sensitivity for poorly-differentiated HCC but a lower sensitivity for highly-differentiated and fibrolamellar variants [19]. The GPC3 mRNA was found to be overexpressed in more than $80 \%$ of HCC cases associated with viral hepatitis and in $76 \%$ of non-viral HCC cases [24]. However, the measuring of serum GPC3 level was less sensitive $(55.2 \%)$ while retaining a high specificity (84.2\%). The GPC3 combination with AFP was uncovered to be more effective for HCC diagnosis with $75.7 \%$ sensitivity and $83.3 \%$ specificity [25]. Thus, we have chosen GPC3 as a "reference" HCC biomarker and compared the data obtained for PDGFA to the GPC3 performance.

Performed analysis of the expression data from our HCC set and publicly available databases revealed the frequent $P D G F A$ overexpression in HCC tissue. Though PDGFA was previously reported to be overexpressed in HCC [26], no detailed investigation on its expression alteration or its potential as a HCC biomarker has been published to date.

A high rate of $P D G F A$ up-regulation in 19 examined hepatitis-negative HCC cases was comparable to that of GPC3. However, PDGFA did not perform so well in larger and less homogenous datasets exhibiting a lower sensitivity than GPC3. While most cases from publicly available datasets demonstrated upregulation of both $P D G F A$ and GPC3, there were subsets with mutually exclusive overexpression of PDGFA or GPC3 indicating that their combination could perform better than each biomarker separately. Indeed, if 2-fold increase in the expression level of either PDGFA or GPC3 was taken as cut-off, the sensitivity of HCC detection considerably increased up to $93.6 \%$. The analysis of biomarkers discriminatory power revealed that PDGFA and GPC3, when combined, distinguished HCC from NT tissue of the same patients better than PDGFA or GPC3 individually. 
PDGFA, a secretable protein detectable in patient's serum, may be considered as a potential HCC diagnostic marker at the mRNA or protein levels especially when used in combination with GPC3 to significantly improve its low sensitivity. The association of $P D G F A$ up-regulation with better overall survival of the patients with BCLC-0 and BCLC-A early HCC stages and a weaker invasion of tumor cells into blood vessels demonstrates that it can be accounted as a prognostic factor. However, this putative prognostic impact is limited since it is not observed in the groups with BCLC stages B and C. Hence, the PDGFA upregulation may be considered as a factor of favorable prognosis but the validation of this hypothesis requires further studies of larger patient cohorts.

\section{Conclusion}

The present study demonstrates that PDGFA is frequently overexpressed in HCC tissue. The combination of PDGFA and GPC3 performs well in distinguishing $\mathrm{HCC}$ and NT tissue when detected at the mRNA level. PDGFA up-regulation might have a prognostic potential for the patients with early $\mathrm{HCC}$ stages. We suggest that PDGFA may be a promising HCC diagnostic biomarker. Further studies focused on the detection of PDGFA in tumor tissue and serum of the HCC patients are necessary to define its efficiency (either alone or in combination with other biomarkers) and the validity for improving sensitivity of the early HCC stages detection.

\section{Funding}

The work was partly supported by grant from Russian Ministry of Education and Science (contract 14.607.21.0049, RFMEFI60714X0049).

\section{REFERENCES}

1. Colagrande S, Inghilesi AL, Aburas S, Taliani GG, Nardi C, Marra F. Challenges of advanced hepatocellular carcinoma. World J Gastroenterol. 2016;22(34):7645-59.

2. Ferlay J, Soerjomataram I, Dikshit R, Eser S, Mathers $C$, Rebelo M, Parkin DM, Forman D, Bray F. Cancer incidence and mortality worldwide: sources, methods and major patterns in GLOBOCAN 2012. Int J Cancer. 2015;136(5):E359-86.
3. Marquardt JU, Galle PR, Teufel A. Molecular diagnosis and therapy of hepatocellular carcinoma (HCC): an emerging field for advanced technologies. J Hepatol. 2012;56(1):267-75.

4. Abelev GI, Eraiser TL. Cellular aspects of alpha-fetoprotein reexpression in tumors. Semin Cancer Biol. 1999;9(2):95-107.

5. Behne T, Copur MS. Biomarkers for hepatocellular carcinoma. Int J Hepatol. 2012;2012:859076.

6. Rich N, Singal AG. Hepatocellular carcinoma tumour markers: current role and expectations. Best Pract Res Clin Gastroenterol. 2014;28(5):843-53.

7. Kotelnikova EA, Logacheva MD, Nabieva ER, Pyatnitskiy $M A$, Vinogradov $D V$, Makarova AS, Demin AV, Paleeva $A G$, Kremenetskaya OS, Penin AA, Klepikova AV, Kasianov AS, Shavochkina DA, Kudashkin NE, Patyutko YuI, Mugue NS, Kondrashov AS, Lazarevich NL. NGS-based identification of druggable alterations and signaling pathways - hepatocellular carcinoma case report. Biopolym Cell. 2015; 31(6):436-46.

8. Bustin SA, Benes V, Garson JA, Hellemans J, Huggett J, Kubista M, Mueller R, Nolan T, Pfaff MW, Shipley GL, Vandesompele J, Wittwer CT. The MIQE guidelines: minimum information for publication of quantitative real-time PCR experiments. Clin Chem. 2009;55(4):611-22.

9. Fu LY, Jia HL, Dong QZ, Wu JC, Zhao Y, Zhou HJ, Ren N, Ye $Q H$, Qin $L X$. Suitable reference genes for real-time PCR in human HBV-related hepatocellular carcinoma with different clinical prognoses. BMC Cancer. 2009;9:49.

10. Gao Q, Wang XY, Fan J, Qiu SJ, Zhou J, Shi YH, Xiao YS, $X u$ Y, Huang $X W$, Sun J. Selection of reference genes for real-time PCR in human hepatocellular carcinoma tissues. J Cancer Res Clin Oncol. 2008;134(9):979-86.

11. Roessler S, Jia HL, Budhu A, Forgues M, Ye QH, Lee JS, Thorgeirsson SS, Sun Z, Tang ZY, Qin LX, Wang XW. A unique metastasis gene signature enables prediction of tumor relapse in early-stage hepatocellular carcinoma patients. Cancer Res. 2010;70(24):10202-12.

12. Huang $Q$, Lin B, Liu H, Ma X, Mo F, Yu W, Li L, Li H, Tian T, Wu D, Shen F, Xing J, Chen ZN. RNA-Seq analyses generate comprehensive transcriptomic landscape and reveal complex transcript patterns in hepatocellular carcinoma. PLoS One. 2011;6(10):e26168.

13. Yu K, Ganesan K, Tan LK, Laban M, Wu J, Zhao XD, Li H, Leung CH, Zhu Y, Wei CL, Hooi SC, Miller L, Tan P. A precisely regulated gene expression cassette potently modulates metastasis and survival in multiple solid cancers. PLoS Genet. 2008;4(7):e1000129.

14. Dong H, Zhang L, Qian Z, Zhu X, Zhu G, Chen Y, Xie X, Ye $Q$, Zang J, Ren Z, Ji Q. Identification of HBV-MLL4 Integration and Its Molecular Basis in Chinese Hepatocellular Carcinoma. PLoS One. 2015;10(4):e0123175.

15. Liu G, Hou G, Li L, Li Y, Zhou W, Liu L. Potential diagnostic and prognostic marker dimethylglycine dehydrogenase 
(DMGDH) suppresses hepatocellular carcinoma metastasis in vitro and in vivo. Oncotarget. 2016;7(22):32607-16.

16. Anders $S$, Huber $W$. Differential expression analysis for sequence count data. Genome Biol. 2010;11(10):R106.

17. Adnane L, Trail PA, Taylor I, Wilhelm SM. Sorafenib (BAY 43-9006, Nexavar), a dual-action inhibitor that targets RAF/ MEK/ERK pathway in tumor cells and tyrosine kinases VEGFR/PDGFR in tumor vasculature. Methods Enzymol. 2006;407:597-612.

18. Makarova AS, Lazarevich NL. Deregulation of signaling pathways involved in sorafenib resistance of hepatocellular carcinoma. Klin Lab Diagn. 2013;(10):66-8.

19. Shafizadeh $N$, Ferrell LD, Kakar S. Utility and limitations of glypican-3 expression for the diagnosis of hepatocellular carcinoma at both ends of the differentiation spectrum. Mod Pathol. 2008;21(8):1011-8.

20. Bruix J, Reig M, Sherman M. Evidence-Based Diagnosis, Staging, and Treatment of Patients With Hepatocellular Carcinoma. Gastroenterology. 2016;150(4):835-53.

21. Henry NL, Hayes DF. Cancer biomarkers. Mol Oncol. 2012;6(2):140-6.

22. Marrero JA, Feng Z, Wang Y, Nguyen MH, Befeler AS, Roberts LR, Reddy KR, Harnois D, Llovet JM, Normolle D, Dalhgren J, Chia D, Lok AS, Wagner PD, Srivastava S, Schwartz $M$. Alpha-fetoprotein, des-gamma carboxyprothrombin, and lectin-bound alpha-fetoprotein in early hepatocellular carcinoma. Gastroenterology. 2009;137(1):110-8.

23. Tsuchiya N, Sawada Y, Endo I, Saito K, Uemura Y, Nakatsura T. Biomarkers for the early diagnosis of hepatocellular carcinoma. World J Gastroenterol. 2015;21(37):10573-83.

24. Hass HG, Jobst J, Scheurlen M, Vogel U, Nehls O. Gene expression analysis for evaluation of potential biomarkers in hepatocellular carcinoma. Anticancer Res. 2015;35(4):2021-8.

25. Jia X, Liu J, Gao Y, Huang Y, Du Z. Diagnosis accuracy of serum glypican-3 in patients with hepatocellular carcinoma: a systematic review with meta-analysis. Arch Med Res. 2014;45(7):580-8.

26. Wei T, Zhang LN, Lv Y, Ma XY, Zhi L, Liu C, Ma F, Zhang XF. Overexpression of platelet-derived growth factor receptor alpha promotes tumor progression and indicates poor prognosis in hepatocellular carcinoma. Oncotarget. 2014;5(21):10307-17.

Ідентифікація PDGFA як можливого біомаркера, що секретусться, гепатоцелюлярної карциноми на підставі транскриптомного аналізу.

М. С. Чесноков, О. М. Кривцова, П. А. Сковороднікова, А. С. Макарова, И. Ф. Кустова, М. Д. Логачова, А. А. Пенін, А. В. Клепікова, Д. А. Шавочкіна, Н. Е. Кудашкін, Е. А. Мороз, Ю. В. Патютко, Е. А. Котельнікова, Н. Л. Лазаревич

Мета. Для діагностики гепатоцелюлярної карциноми (ГК) ідентифкація потенційних біомаркерів, що секретується.
Методи. Гени, експресія яких підвищена в тканині ГК і які кодують білки, що секретуються, виявляли РНК-секвенуванням. Експресію генів оцінювали ЗТ-ПЛР або використовували інформацію з відкритих баз даних. Біомаркерні властивості оцінювали за допомогою ROC-кривих, аналізу кореляцій і виживання. Результати. РНК-секвенування п'яти випадків ГК виявило гіперекспресію PDGFA, що кодує секретуємий білок. Підвищення експресії PDGFA та GPC3 виявлено в 17 з 19 зразків ГК та у більшості випадків з баз даних. Комбінація з $P D G F A$ та GPC3 розрізнює тканину ГК і непухлинну тканину печінки краще, ніж PDGFA або GPC3 окремо. Гіперекспресія PDGFA асоційована 3 кращим прогнозом для пацієнтів 3 ранніми стадіями ГК і низькою інвазією пухлини в судини. Висновки. PDGFA - перспективний біомаркер ГК, що секретується, який може бути використаний разом 3 GPC3 для підвищення його чутливості.

Keywords: hepatocellular carcinoma; PDGFA; tumor biomarker; NGS

\section{Идентификация PDGFA как возможного секретируемого биомаркера гепатоцеллюлярной карциномы на основании транскриптомного анализа. \\ М. С. Чесноков, О. М. Кривцова, П. А. Сковородникова, А. С. Макарова, И. Ф. Кустова, М. Д. Логачева, А. А. Пенин, А. В. Клепикова, Д. А. Шавочкина, Н. Е. Кудашкин, Е. А. Мороз, Ю. И. Патютко, Е. А. Котельникова, Н. Л. Лазаревич}

Цель. Поиск потенциальных секретируемых биомаркеров для диагностики гепатоцеллюлярной карциномы (ГК). Методы. Гены, экспрессия которых повышена в ткани ГК и кодирующие секретируемые белки, выявляли РНК-секвенированием. Экспрессию генов оценивали ОТ-ПЦР или использовали информацию из открытых баз данных. Биомаркерные свойства оценивали с помощью ROC-кривых, анализа корреляций и выживаемости. Результаты. РНК-секвенирование 5 случаев ГК выявило гиперэкспрессию $P D G F A$, кодирующего секретируемый белок. Повышение экспрессии PDGFA и GPC3 выявлено в 17 из 19 образцов ГК и в большинстве случаев из баз данных. Совместное использование двух маркерных генов $P D G F A$ и GPC3 позволяет дифференцировать ткань ГК от неопухолевой ткани печени лучше, чем PDGFA или GPC3 по отдельности. Гиперэкспрессия $P D G F A$ ассоциирована с лучшим прогнозом для пациентов с ранними стадиями ГК и низкой инвазией опухоли в сосуды. Выводы. PDGFA - перспективный секретируемый биомаркер ГК, который может быть использован вместе с GPC3 для повышения его чувствительности.

Keywords: hepatocellular carcinoma; PDGFA; tumor biomarker; NGS

Received 01.11.2016 